TAO, Vol. 16, No. 3, 641-651, August 2005

\title{
Composition and Trace Element Content of Coal in Taiwan
}

\author{
Louis-Yie Tsai $^{1{ }^{*}}$, Chia-Fen Chen ${ }^{1}$ and Robert B. Finkelman ${ }^{2}$ \\ (Manuscript received 3 November 2004, in final form 13 June 2005)
}

\begin{abstract}
To investigate the trace element contents of local coal, four coal samples were collected from operating mines in NW Taiwan. Detailed petrographic and chemical characterization analyses were then conducted. Analytical results indicate that (1) the samples were high volatile bituminous coal in rank with ash content ranging from 4.2 to $14.4 \%$ and with moisture content ranging from 2.7 to $4.6 \%$; (2) the macerals were mostly composed of vitrinite with vitrinite reflectance less than $0.8 \%$; (3) the sample of Wukeng mine has the highest $\mathrm{Fe}_{2} \mathrm{O}_{3}(29.5 \%)$, Tl (54.8 ppm), Zn (140 ppm), and As $(697 \mathrm{ppm})$ contents in ash and $\mathrm{Hg}(2.3 \mathrm{ppm})$ in the coal. If used properly, these coals should not present health hazards.
\end{abstract}

(Key words: Trace element, Coal ash, Petrographic analysis)

\section{INTRODUCTION}

Coal seams usually originate from peat deposited in swamps, especially a stable, continually subsiding swamp in a warm and humid climate. Besides the major elements $\mathrm{C}, \mathrm{H}, \mathrm{O}, \mathrm{N}, \mathrm{S}$, trace elements $(<1 \mathrm{wt} \%)$ may also reflect the depositional environment of peat. Furthermore, a better knowledge of coal quality parameters may help to minimize some of the health problems caused by coal use. Information about the concentration and distribution of potentially toxic elements in coal may assist people to avoid those areas of coal deposit having high concentration of these elements. The purpose of this study is to evaluate the depositional environments and public health concerns of four operating coalmines in Taiwan, by analyzing the coal composition and trace element contents.

\footnotetext{
${ }^{1}$ Institute of Applied Geology, National Central University, Chung-Li, Taiwan, ROC

${ }^{2}$ U. S. Geological Survey, Reston, Virginia 20192, USA

* Corresponding author address: Prof. Louis L. Tsai, Institute of Applied Geology, National Central University, Chung-Li, Taiwan, ROC; E-mail: Itsai@geo.ncu.edu.tw
} 


\section{LITERATURE REVIEW}

Goldschmidt (1935) was the first to study the abundances of trace elements in coal ash. Swaine (1975) discussed the concentration, origin and enrichment of trace elements in coal. Gluskoter et al. (1981) described the affinity of trace elements according to their association with organic or inorganic materials in coal. Finkelman (1981) pointed out that in a low rank coal such as lignite and sub-bituminous coal, trace elements such as $\mathrm{Na}, \mathrm{Mg}, \mathrm{Ca}, \mathrm{Sr}$, and $\mathrm{Ba}$ usually associated with organic constituents in coal. Finkelman (1982) then studied the modes of occurrence of trace elements in detail.

Pareek and Bardhan (1985) had studied the association of trace elements with macerals and found that $\mathrm{Cu}, \mathrm{Ni}, \mathrm{Co}, \mathrm{V}, \mathrm{Ga}$, and $\mathrm{B}$ usually associated with vitrinite, although $\mathrm{Cu}$ and $\mathrm{Ni}$ can originate from both organic and inorganic sources. Martinez-Tarazona et al. (1992) believed that most of the trace elements in bituminous coal were concentrated in detritus and diagenetic minerals. Lu et al. (1995) investigated the distribution of trace elements of coal in China, Spears and Zheng (1999) studied the origin of elements in UK coal, whereas Helle et al. (2000) completed the chemical characterization of coals from Chile. Their results indicate a similar organic/inorganic association trend.

Chou (1984) studied the geochemistry of coal and overlying strata in the Illinois Basin, U.S.A. He concluded that high-sulfur coal is also enriched in $\mathrm{Mo}, \mathrm{B}, \mathrm{U}, \mathrm{Fe}, \mathrm{Tl}$, and $\mathrm{Hg}$ relative to low-sulfur coal. The excess amounts of S, Mo, B, and U in high-sulfur coal were probably derived from seawater that flooded the swamp and stopped peat deposition, because concentrations of these elements in seawater are much higher than those in fresh water. On the other hand, concentrations of $\mathrm{Fe}, \mathrm{Tl}$, and $\mathrm{Hg}$ are extremely low in seawater. Therefore, it is suggested that $\mathrm{Fe}, \mathrm{Tl}$, and $\mathrm{Hg}$ were derived from a terrigenous source by weathering and were transported to the swamp by rivers. Furthermore, chalcophile elements ( $\mathrm{Mo}, \mathrm{Fe}, \mathrm{Tl}$, and $\mathrm{Hg}$ ) were incorporated in pyrite during the early diagenesis of peat in a sulfur-rich and reducing environment. B and $\mathrm{U}$ were associated predominantly with the organic matter.

Some of the trace elements were found to be a good indicator of their depositional environment. Bouska (1981) pointed out that $\mathrm{Th} / \mathrm{U}>7$ in terrestrial sediments whereas it is $<7$ in marine sediments. Furthermore, the higher $\mathrm{Th} / \mathrm{U}$ ratio indicates a more oxidized environment. Taylor and McLennan (1985) had studied the Th/U in Post-Archean shale and adjusted the terrestrial-marine threshold to 4.8. Gayer et al. (1999) also concluded the lower Th/U ratio was found in a more reductive, marine influenced coal seam.

In addition, Chao et al. (1994) pointed out the $\mathrm{SiO}_{2}$ and $\mathrm{Al}_{2} \mathrm{O}_{3}$ contents can be used as indicators of terrestrial-prone depositional environments, whereas the $\mathrm{CaO}, \mathrm{MgO}$ and $\mathrm{Fe}_{2} \mathrm{O}_{3}$ contents can be used as indicators of marine-prone depositional environments, because of their weathering-resist properties. They also proposed a $\left(\mathrm{CaO}+\mathrm{MgO}+\mathrm{Fe}_{2} \mathrm{O}_{3}\right) /\left(\mathrm{SiO}_{2}+\right.$ $\mathrm{Al}_{2} \mathrm{O}_{3}$ ) ratio higher or lower than 0.22 indicating a strong or weak reductive depositional environment for humic coals, respectively. Tang et al. (1996) further discussed how the ratios of $\mathrm{Sr} / \mathrm{Ba}$ and $\mathrm{B} / \mathrm{Ga}$ could be used as indicators of a depositional environment. According to them, $\mathrm{Sr} / \mathrm{B}$ a ratio $0.1 \sim 0.6,0.7 \sim 1.2,1.3 \sim 1.6$ and $\mathrm{B} / \mathrm{Ga}$ ratio $<4,4 \sim 10,>10$ implied terrestrial, littoral to brackish water, and marine depositional environments, respectively.

As for public health concerns, Finkelman et al. (1999) studied the health impacts of 
domestic coal use in China. They found that certain local diseases in SW China could be attributed to As, $\mathrm{Hg}, \mathrm{F}$, Se poisoning by trace element emissions from residential coal burning. Information on the modes of occurrence of these toxic elements and the textural relations of the minerals and macerals may help predict the behavior of the potentially toxic components during coal combustion.

\section{LOCAL COAL GEOLOGY}

Ho (1983) studied and mapped in detail nearly all of the major coalfields in northern Taiwan. Tsai (1988) evaluated the paragenetic relationship between coalification and tectonic movement by studying the orientation of the reflectance indicatrix of vitrinite. Hsiao and $\mathrm{Hu}$ (1990) combined various geologic and geophysical plus well-logging data and made a complete Tertiary basin analysis of western Taiwan. Their investigation includes stratigraphic correlation, sedimentary study, tectonic evolution, and reservoir analyses. In addition, Tsai and Sun (1993) conducted a study on coal petrology and hydrocarbon generation in HsinchuMiaoli area, NW Taiwan. They concluded that the variation of coal rank reflected the depositional environment, burial metamorphism and tectonic activities.

The Shihti Formation is the most important coal-bearing formation in Taiwan. It consists of bluish-gray to light brown sandstone and dark gray micaceous shale. Seven mineable coal seams are included with their thicknesses mostly less than one meter thick each. The Miocene formations were deformed due to the Penglai Orogeny starting from the Plio-Pleistocene. The geologic structures in the study area include folds and faults more or less along a NE-SW direction. Most of the folds are asymmetric anticlines with steeper NW limbs whereas most of the faults are imbricate thrust faults with SE-dipping fault planes.

As for local sedimentary studies, Chou (1976) finished a sedimentologic and paleogeographic study of the Shihti Formation in western Taiwan. In addition, Yu and Teng (1996, 1999) and Yu et al. (1999) studied the facies characteristics and depositional environment as well as sea-level changes in the Miocene strata of northern Taiwan. According to them, the Shihti Formation was deposited in a tide-influenced coastal plain and a low-energy waveinfluenced shelf environment, probably embracing delta plains, estuaries, swamps, lagoons, beaches, and shallow neritic environments.

\section{SAMPLING AND ANALYTIC METHODS}

Grab coal samples were collected from four operating mines in NW Taiwan, the Lifeng, Yufeng, Anshuen, and Wukeng mines. All of the samples belong to the middle Miocene Shihti Formation and are located in the Western Foothill Belt of Taiwan (Fig. 1). According to local mining information, Wukeng mine, Anshuen mine, Yufeng mine and Lifeng mine were operating on coals from the uppermost, main, lower, and lowest coal seams in the Shihti Formation. Detailed petrography and chemical characterization analyses were then conducted. Sample collection and preparation and analytical methods including Proximate, Ultimate, atomic absorption spectroscopy, X-ray fluorescence, specific-ion electrode, neutron activation analysis, 


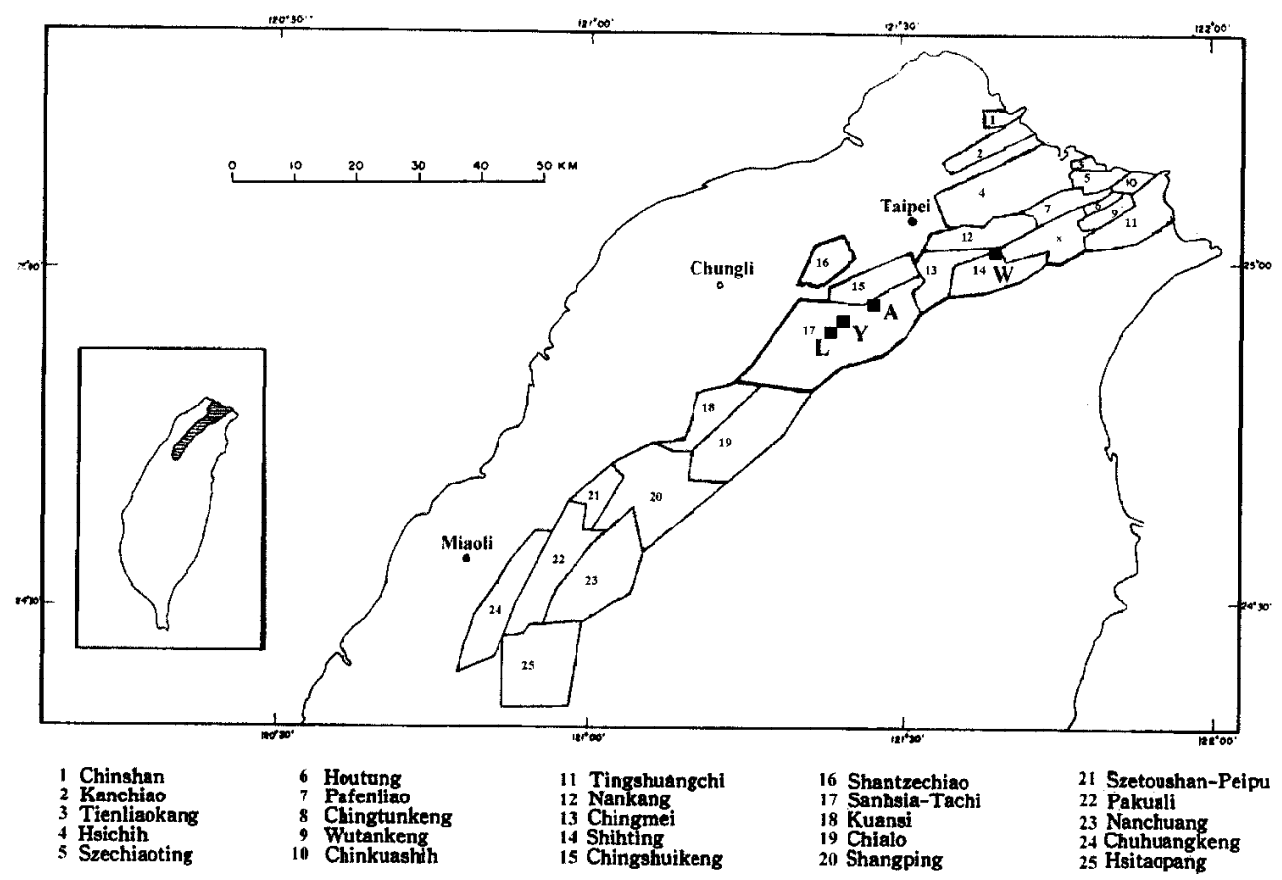

Fig. 1. The location and sampling sites of coalfields in the Western Foothill Belt of Taiwan; 1 25 coalfields, A: Anshuen mine, L: Lifeng mine, Y: Yufeng mine, W: Wukeng mine.

and spectra-photometric were all conducted according to ASTM procedures and U.S. Geological Survey (USGS) guidelines (Fig. 2).

\section{ANALYTICAL RESULTS}

\subsection{Proximate and Ultimate Analysis}

According to USGS, the results of Proximate (Industrial) analysis and Ultimate (Elemental) analysis are listed in Table 1.

\subsection{Maceral Composition and Vitrinite Reflectance}

Maceral composition and vitrinite reflectance were further analyzed and listed in Table 2. According to the data in sections 5.1 and 5.2, the samples were high volatile bituminous coal in rank with ash yields ranging from 4.2 to $14.4 \%$ and moisture content ranging from 2.7 to 4 . $6 \%$. Furthermore, the macerals were mostly composed of vitrinite. The pyrite (1.79\%) and 


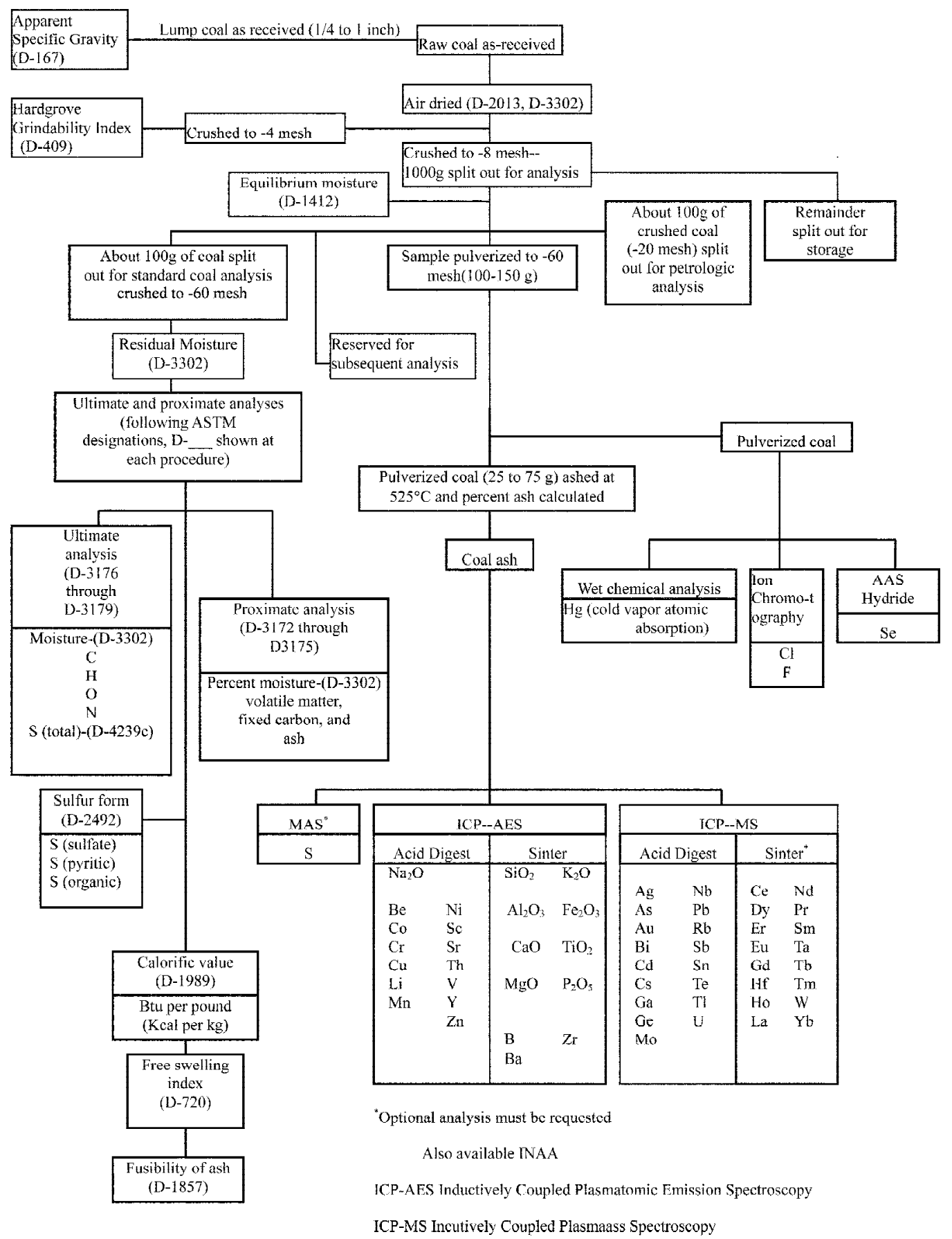

Fig. 2. Flow chart of the analytic methods used by the U.S. Geological Survey at the time the coal samples were analyzed (2001). 
Table 1. Proximate and Ultimate analysis results of samples; Ssul, Spy, and Sorg represent sulfate $\mathrm{S}$, pyritic $\mathrm{S}$, and organic $\mathrm{S}$ contents, respectively.

\begin{tabular}{|lcccc|}
\hline & Moisture(\%) & Ash(\%) & Volatile matter(\%) & Fixed Carbon(\%) \\
\hline Anshuen & 2.75 & 5.91 & 40.44 & 53.65 \\
\hline Yufeng & 2.72 & 4.18 & 43.27 & 52.55 \\
\hline Lifeng & 2.69 & 14.36 & 37.03 & 48.61 \\
\hline Wukeng & 4.61 & 10.05 & 45.04 & 44.91 \\
\hline
\end{tabular}

\begin{tabular}{|lcccccccc|}
\hline & $\mathrm{C}(\%)$ & $\mathrm{H}(\%)$ & $\mathrm{N}(\%)$ & $\mathrm{O}(\%)$ & $\mathrm{S}(\%)$ & $\mathrm{Ssul}(\%)$ & $\mathrm{Spy}(\%)$ & $\mathrm{Sorg}(\%)$ \\
\hline Anshuen & 78.18 & 5.26 & 1.88 & 7.94 & 0.83 & 0.08 & 0.16 & 0.59 \\
\hline Yufeng & 79.18 & 5.66 & 1.69 & 8.53 & 0.76 & 0.07 & 0.14 & 0.55 \\
\hline Lifeng & 70.64 & 4.95 & 1.74 & 7.55 & 0.76 & 0.04 & 0.19 & 0.53 \\
\hline Wukeng & 70.27 & 5.21 & 1.71 & 9.95 & 2.81 & 0.37 & 1.79 & 0.65 \\
\hline
\end{tabular}

Table 2. Maceral composition and vitrinite reflectance of samples.

\begin{tabular}{|lccccc|}
\hline & Vitrinite(\%) & Exinite(\%) & Inertinite(\%) & Mineral Matter(\%) & Ro(\%) \\
\hline Anshuen & 95.00 & 1.75 & 0.00 & 3.25 & 0.81 \\
\hline Yufeng & 88.50 & 6.63 & 0.62 & 4.25 & 0.71 \\
\hline Lifeng & 92.75 & 4.50 & 0.00 & 2.75 & 0.78 \\
\hline Wukeng & 85.50 & 4.00 & 0.00 & 10.50 & 0.42 \\
\hline
\end{tabular}

total sulfur content $(2.81 \%)$ of the Wukeng coal is much higher than the other three coal samples, which can be attributed to the influence of marine transgression close to the final stage of depositional cyclothem, because it was mined from the uppermost coal seams of the Shihti Formation, as previously mentioned.

\subsection{Trace Element Analysis}

The analytical results of trace element contents are listed in Table 3. The enrichment factors were also calculated by comparing to their average crust contents from Horne (1978). 
Tsai et al.
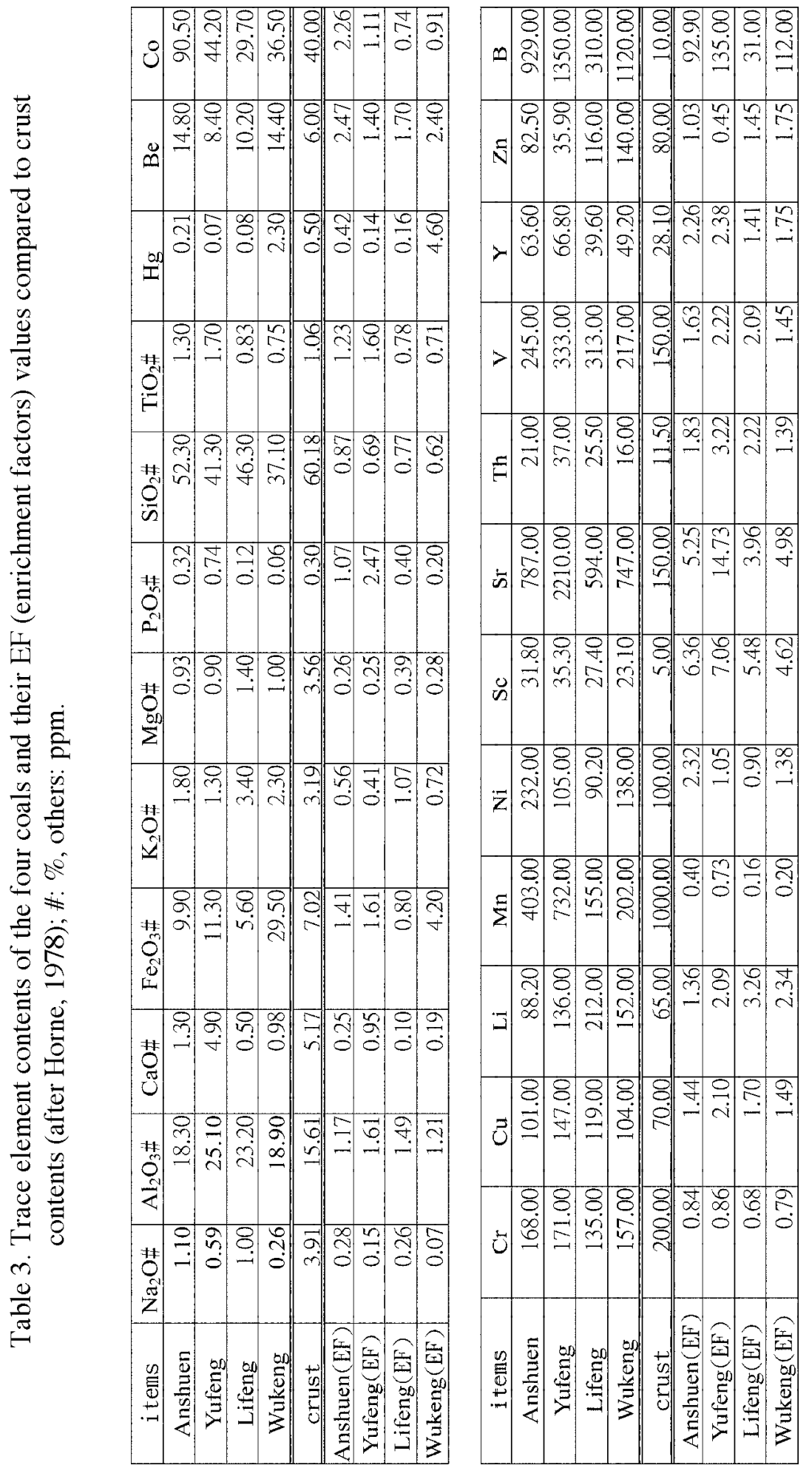


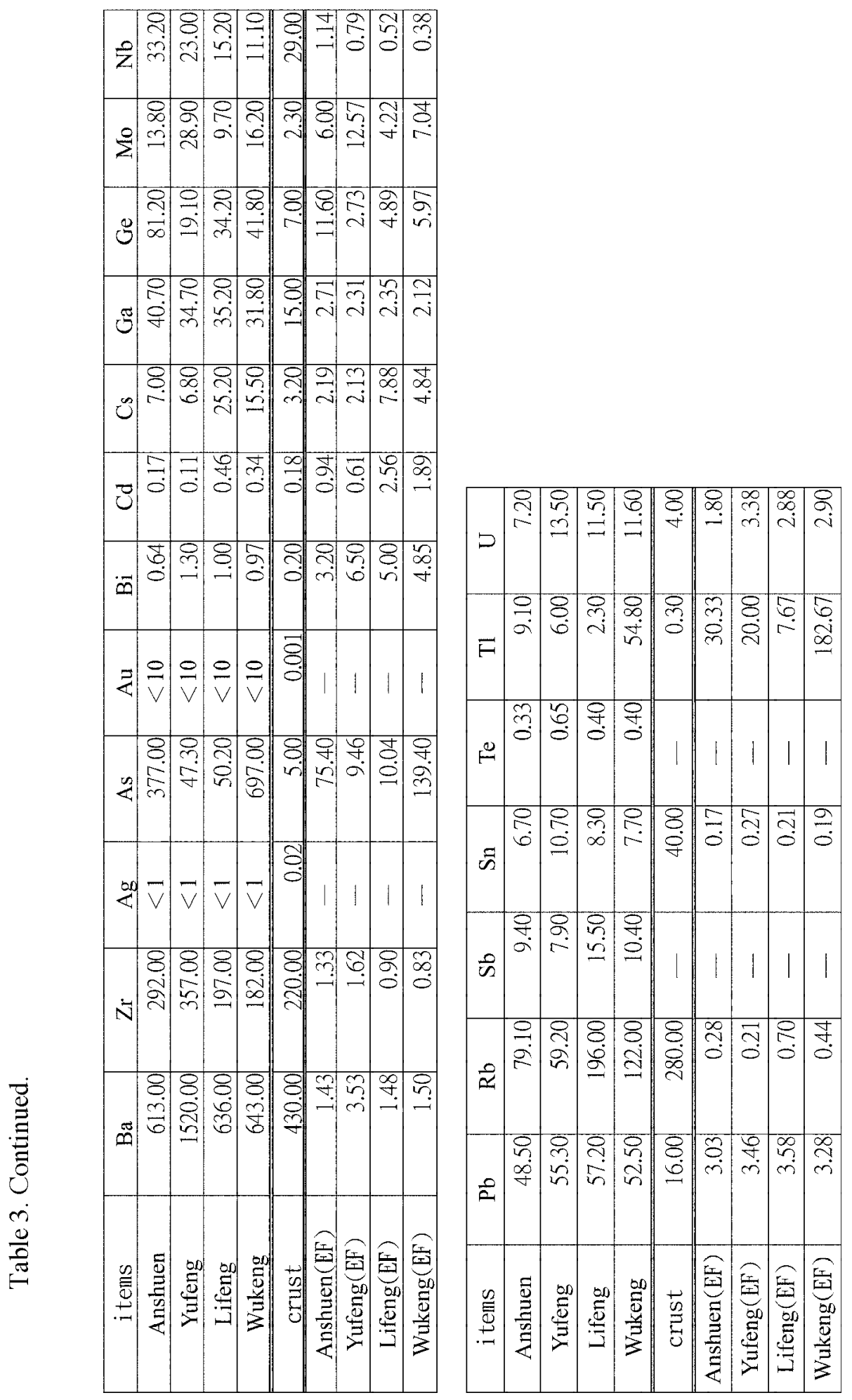


The trace element contents analyzed were not too striking except for the sample from the Wukeng mine, which (in ash) has the highest $\mathrm{Fe}_{2} \mathrm{O}_{3}$ (29.5\%), Tl (54.8 ppm), Zn (140 ppm), and As (697 ppm) contents and $\mathrm{Hg}$ (2.3 ppm on a coal basis). In addition this sample has relatively high $\mathrm{U}$ (11.6 ppm), Be (14.4 ppm), Cs (15.5 ppm), Rb (122 ppm) and B (1120 ppm) contents. It is also noticed that the enrichment factors of $\mathrm{B}, \mathrm{As}$, and $\mathrm{Tl}$ in Wukeng coal are all over 100. In addition, some of the elemental ratios are noticed here:

\begin{tabular}{|lcccc|}
\hline & $\mathrm{Th} / \mathrm{U}$ & $\mathrm{Sr} / \mathrm{Ba}$ & $\mathrm{B} / \mathrm{Ga}$ & $\left(\mathrm{CaO}+\mathrm{MgO}+\mathrm{Fe}_{2} \mathrm{O}_{3}\right) /\left(\mathrm{SiO}_{2}+\mathrm{Al}_{2} \mathrm{O}_{3}\right)$ \\
\hline Anshuen & 2.80 & 1.28 & 22.83 & 0.17 \\
\hline Yufeng & 2.74 & 1.45 & 38.90 & 0.26 \\
\hline Lifeng & 2.22 & 0.93 & 8.81 & 0.11 \\
\hline Wukeng & 1.38 & 1.16 & 35.22 & 0.56 \\
\hline
\end{tabular}

Comparing with the discussions from Chou (1984), Chao et al. (1994) and Tang et al. (1997), although they are somewhat inconsistent, the elemental ratios still imply a reductive, littoral to brackish swamp environment during deposition. The inconsistency of elemental ratio can be attributed to differences in plant species, geologic time and local tectonic activities. In addition, the Wukeng coal and Yufeng coal exhibit high $\mathrm{B}$, Mo, and $\mathrm{U}$ contents as well as high ratios in both $\mathrm{B} / \mathrm{Ga}$ and $\left(\mathrm{CaO}+\mathrm{MgO}+\mathrm{Fe}_{2} \mathrm{O}_{3}\right) /\left(\mathrm{SiO}_{2}+\mathrm{Al}_{2} \mathrm{O}_{3}\right)$, which indicate more marine influence during deposition. Furthermore, as previously mentioned, the enrichment of $\mathrm{Fe}_{2} \mathrm{O}_{3}, \mathrm{Tl}$ and $\mathrm{Hg}$ in the high-sulfur Wukeng coal might be derived from a terrigenous source by weathering, and transported to the swamp by rivers. As for the high As and $\mathrm{Zn}$ contents in Wukeng coal, it can be interpreted as incorporation in pyrite during peatification.

After examining studies of local depositional environments done by Chou (1976), Yu and Teng $(1996,1999)$ and Yu et.al. (1999), the coals from the Lifeng, Yufeng, and Anshuen mines are concluded to be deposited in a lagoon or swamp whereas the coal in the Wukeng mine is believed to have formed in a delta.

\section{DISCUSSION AND CONCLUSION}

The concentrations of toxic trace elements in most of the samples analyzed were found to be less than the levels in most U.S. and China coals (Finkelman et al., 1999), which has been shown not to be dangerous to human health. Thus, proper use of the coals studied should not result in significant health concerns regarding exposure to potentially toxic trace elements.

The analytic results indicate a reductive, littoral to brackish swamp environment during deposition. The high pyrite content in Wukeng is associated with the enrichment of $\mathrm{B}$, As and $\mathrm{Tl}$, with enrichment factors over 100 by comparing with average trace element contents in crust. The depositional environment of the coals from the Lifeng, Yufeng, and Anshuen mines 
is concluded to be a lagoon or swamp, whereas the depositional environment of the coal from the Wukeng mine is believed to be a delta.

Better knowledge of coal quality parameters may help minimize some of the health problems caused by coal use. Information on the concentration and distribution of toxic elements in coal may help people avoid those areas of a coal deposit having high concentration of toxic elements. Further study is needed to understand the modes of occurrence of elements during the deposition and coalification stage in the study area.

Acknowledgments The authors would like to acknowledge John Bullock, Jr. of the United States Geological Survey for conducting the coal analyses. Dr. C. L. Kuo and his colleagues in the Geochemistry Group of the Exploration and Development Research Institute, Chinese Petroleum Corp., also kindly provided some of the needed analytical equipment. This study could not have been finished without their help. Dr. C. L. Chou and three anonymous reviewers kindly provide constructive suggestions to complete this paper. Finally, National Science Council of Taiwan, R.O.C. is acknowledged for the financial support.

\section{REFERENCES}

Bouska V., 1981: Geochemistry of coal. Academia, Prague, 284 p.

Chao S. C., M. S. Tong, and F. Y. Wang, 1994: Model discussions of environment-typecharacteristics of coalification (I) Environment and facies of deposition.J. Sed., 12, 3239. (in Chinese)

Chou C. L., 1984: Relationship between geochemistry of coal and the nature of strata overlying the Herrin coal in the Illinois Basin, U.S.A. Mem. Geol. Soc. China, 6, 269-280.

Chou J. T., 1976: A sedimentologic and paleogeographic study of the Miocene Shihti Formation in western Taiwan. Petr. Geol. Taiwan, 13, 119-138.

Finkelman R. B., 1981: The origin, occurrence, and distribution of the inorganic constituents in low-rank coal, In: Proceedings of the Basic Coal Science Workshop (Schobert H. H., comp.), Grand Forks Energy Research Center. Grand Forkes, ND., 70-90.

Finkelman, R. B., 1982: Modes of occurrence of trace elements and minerals in coal: an analytical approach. In: Filby R. H., B. S. Carpenter, and R. C. Ragaini, (Eds.), Atomic and nuclear methods in fossil energy research, Plenum Press, NY. 141-149.

Finkelman, R. B., H. E. Belkin, and B. Zheng, 1999: Health impacts of domestic coal use in China. Proc. Nat. Acad. Sci. USA., 96, 3427-3431.

Gayer, R. A., M. Rose, J. Dehmer, and L. Y. Shao, 1999: Impact of sulfur and trace element geochemistry on the utilization of a marine-influenced coal-case study from the South Wales Variscan foreland basin. Int. J. Coal Geol., 40, 151-174.

Gluskoter, H. J., N. F. Shimp, and R. R. Ruch, 1981: Coal analyses, trace elements and mineral matter. In: Elliott M. A., (Ed.), Chemistry of coal utilization, 2nd sup. Vol. Wiley, N.Y., 369-424.

Goldschmidt, V. M., 1935: Rare elements in coal ashes. Ind. Eng. Chem., 27, 1100-1102. 
Helle, S., G. Alfaro, U. Kelm, and J. M. D. Tascon, 2000: Mineralogical and chemical characterization of coals from southern Chile. Int. J. Coal Geol., 44, 85-94.

Ho, C. S., 1983: Geologic structure and coal fields of the area between Keelung and Tachi, Taiwan. Bull. Cent. Geol. Surv., 2, 17-70.

Horne, R. A., 1978: The chemistry of our environment. John Wiley \& Sons, 76, 740-742.

Hsiao, P. T., and C. C. Hu, 1990: Evolution and hydrocarbon potential evaluation of the Tertiary basin of western Taiwan. Bull. Expl. Prod. Res. CPC., 13, 1-13.

Lu, X., H. Zeng, T. Xu, and R. Yan, 1995: Chemometric studies of distribution of trace elements in seven Chinese coals. Fuel, 74, 1382-1386.

Martinez-Tarazona, M. R., D. A. Spears, and J. M. D. Tascon, 1992: Organic affinity of trace elements in Asturian bituminous coals. Fuel, 71, 909-917.

Pareek, H. S., and B. Bardhan, 1985: Trace elements and their variation along seam profiles of certain coal seams of middle and upper Barakar Formations (Lower Permian) in East Bokaro Coalfield, District Hazaribagh, Bihar, India. Int. J. Coal Geol, 5, 281-314.

Spears, D. A., and Y. Zheng, 1999: Geochemistry and origin of elements in some UK coals. Int. J. Coal Geol., 38, 161-179.

Swaine, D. J., 1975: Trace elements in coal. In: Tugatinov A. I., (Ed.), Recent contributions to geochemistry and analysis. Halsted Press, New York, 539-550.

Tang, Y.G., D. Y. Ren, C. F. Liu, G. H. Yao, and C. J. Gan, 1996: Relationships between sulfur content and coalification environment of the late Permian coal in Sichuan. $J$. Sed., 14, 161-167. (in Chinese)

Taylor, S. R., and S. M. McLennan, 1985: The continental crust: its composition and evolution. Blackwell, Oxford, $312 \mathrm{p}$.

Tsai, L. L., 1988: An implication of the paragenetic relationship of vitrinite in coal fields between Keelung and Taipei. Tichih, 8, 63-70.

Tsai, L. L., and L. C. Sun, 1993: Coal petrology and hydrocarbon generation studies of the Nanchuang Formation, Hsinchu-Miaoli area. Petr. Geol. Taiwan., 28, 193-200.

Yu, N. T., and S. L. Teng, 1996: Facies characteristics and depositional cycles of middle and upper Miocene strata of the Western Foothills, northern Taiwan. Tichih, 15, 29-60.

Yu N. T., and Teng S. L., 1999: Depositional environments of the Taliao and Shihti Formations, northen Taiwan. Bull. Cent. Geol. Surv., 12, 99-132.

Yu N. T., Teng S. L., Tai P. C., and Yue L. F., 1999: Relative sea-level changes in Oligocene to Miocene strata in northern Taiwan: a preliminary study. J. Geol. Soc. China., 42, 189-208. 